\title{
Neo- and epitypification of Arundinaria nitida (Poaceae: Bambusoideae)
}

\author{
Chris Stapleton ${ }^{1}$ \& Gea Zijlstra ${ }^{2}$ \\ 111 Chandos Close, Amersham, Bucks HP6 6PJ, U.K. \\ 2 Laboratory of Palaeobotany \& Palynology, Budapestlaan 4, 3584 CD Utrecht, The Netherlands \\ Author for correspondence: Chris Stapleton,chris@bamboo-identification.co.uk \\ ORCID: CS, http://orcid.org/0000-0002-6672-8075; GZ, http://orcid.org/0000-0001-9894-9967 \\ DOI http://dx.doi.org/10.12705/642.26
}

\begin{abstract}
A neotype and an epitype from the widely cultivated Fountain Bamboo are proposed for Arundinaria nitida. Application and authorship of the name are discussed, in the light of confusion over the validity of this name in different publications, and the implications of selecting different types for the application of generic names.
\end{abstract}

Keywords Arundinaria; China; epitype; Fargesia; neotype; Sinarundinaria; typification

\section{口 INTRODUCTION}

Seed of a temperate bamboo was collected in Gansu Province of W China in 1886, and small plants obtained by the Royal Botanic Gardens, Kew in June 1892. The species was destined to become one of the most widely cultivated ornamental clumpforming bamboos, known as the Fountain Bamboo. It was identified at Kew as Arundinaria khasiana Munro, another species with dark culms, from the Khasia Hills of India, known from herbarium collections to have been in cultivation at Kew in 1877. The Fountain Bamboo was briefly described under the name $A$. khasiana in a review of hardy bamboos in cultivation in Europe by Kew horticulturalist William Bean (1894). Greatly impressed with these new plants growing at Kew, Algernon Freeman-Mitford, a British diplomat with Oriental experience, having discovered their true origin from China rather than India, decided that they represented a new species, and in a lecture in London he used the new name, Arundinaria nitida. The lecture was not published until the following year (Mitford, 1896). Meanwhile, the name was used without a description, by an anonymous editor (1895: 186) reporting on Mitford's lecture, including a photograph (fig. 33) of a clump of Fountain Bamboo growing at Kew, and referring to the earlier, brief description of A. khasiana in cultivation by Bean (1894).

Kew taxonomist Otto Stapf described Arundinaria nitida in much greater detail (1896), citing the anonymous publication (1895) as "nomen solum". There has been a strong tradition to attribute Stapf with authorship of $A$. nitida, and to discount publication in the rather ambiguous, anonymous editorial, and the equally ambiguous description of the cultivated specimens of "A. khasiana" by Bean (1894). Stapf (1896) cited two syntypes. One was from a plant grown in St Petersburg from the same seed collection as the Fountain Bamboo at Kew. The other, belonging to a different species from a different province, Hubei, was erroneously included by Stapf (1896), probably because the Fountain Bamboo syntype was sterile.
"Arundinaria nitida Stapf" was formally lectotypified (Stapleton, 1995), in order to maintain application of the name to the cultivated Fountain Bamboo, rather than to the species from Hubei. McClure (1940) had already separated out the Hubei syntype as a distinct new species, Indocalamus confusus McClure, and annotated the remaining syntype as lectotype, but he did not explicitly publish the lectotypification. This implicit lectotypification was duly formalised (Stapleton, 1995), which is in accordance with Rec. 9A.4 of the Melbourne Code (McNeill \& al., 2012).

\section{口 RELATED SPECIES}

Application of the name Arundinaria nitida had become important for the application of three generic names for two groups of temperate bamboos, which vary in compression of inflorescences, and in rhizome form, which determines whether they grow in clumps or spread. Franchet (1893) had previously described Fargesia Franch. from a Chinese flowering specimen of $F$. spathacea Franch., which has compressed spathed inflorescences. Nakai (1935) in Japan, having received plants of two Chinese species from Kew, Fountain Bamboo, A. nitida, and the similar Umbrella Bamboo, A. murielae Gamble, described Sinarundinaria Nakai solely for the sterile plants of $A$. nitida and $A$. murielae that he had received. The three species $F$. spathacea, A. nitida and A. murielae are all clump-forming with relatively short rhizomes.

Keng (1957) described a further genus, Yushania Keng f. for spreading species with long-necked pachymorph rhizomes and open unspathed inflorescences, with a type from Taiwan.

As reported by Stapleton (1995), application of these generic names in mainland China became controversial in the 1980s. Although originally Chinese plants, F. spathacea, Fountain Bamboo and Umbrella Bamboo were not well known in China. Nakai (1935) had erroneously attributed them and his

Received: 27 Mar 2014 | returned for (first) revision: 24 Feb 2015 | (last) revision received: 10 Mar 2015 | accepted: 10 Mar 2015 || publication date(s): online fast track, 7 Apr 2015; in print and online issues, 6 May 2015 || C International Association for Plant Taxonomy (IAPT) 2015 
new genus Sinarundinaria with having long rhizomes, which caused confusion in China.

Chao \& al. (1981) reported finding a Chinese species in the wild that they identified as Arundinaria nitida. Because the species they found has long-necked pachymorph rhizomes, they decided to reduce Yushania to a synonym of Sinarundinaria. In their opinion Arundinaria nitida was a spreading, not clump-forming bamboo, with long-necked pachymorph rhizomes, which they called Sinarundinaria nitida. Climatic differences were postulated as explaining its clump-forming habit in western cultivation. This was followed by several authorities, including Clayton \& Renvoize (1986) and Chao \& Renvoize (1989).

However, other taxonomists in China included Arundinaria nitida in the purely clump-forming genus Fargesia as F. nitida (Mitford ex Anon.) Keng f. ex T.P.Yi. They recognized Yushania as the correct name for the genus of bamboos with long-necked pachymorph rhizomes and open, unspathed inflorescences. Sinarundinaria was considered by them to be a synonym of Fargesia (Wang \& Ye, 1980). The Stapf syntype of A. nitida erroneously included by him (1896) and separated by McClure as Indocalamus confusus was transferred as Yushania confusa (McClure) Z.P.Wang \& G.H.Ye. The bamboo genera were revised accordingly (Keng, 1982, 1983), and a very large number of new Chinese species were described. The clumpforming species were placed in Fargesia, and spreading species with long-necked pachymorph rhizomes were described in Yushania.

Whether Yushania or Sinarundinaria should be used for the bamboos with open inflorescences and long-necked pachymorph rhizomes could only really be settled by the flowering of the cultivated Fountain Bamboo, revealing whether it had compressed inflorescences, as the earlier Fargesia, or open inflorescences, as the later Yushania.

The flowering of Umbrella Bamboo Arundinaria murielae (Soderstrom, 1979a) had revealed compressed inflorescences, and several authors had consequently placed that species in Fargesia (or Thamnocalamus s.l.) (Soderstrom, 1979b; Yi, 1983). Stapleton (1991) examined branching patterns in A. nitida and Fargesia murielae. From close similarities it was concluded that the inflorescences were also likely to be similar, i.e., compressed, noting that similar flowers had also recently been collected in China and identified as A. nitida.

This uncertainty was settled when compressed inflorescences that were undisputedly from the Fountain Bamboo were first found in the U.K., and Arundinaria nitida was consequently lectotypified by Stapf's syntype from the Fountain Bamboo (Stapleton, 1995), to keep Arundinaria nitida and consequently Sinarundinaria within Fargesia.

Li (1996) considered what would be necessary to follow the alternative approach, in order to allow Sinarundinaria to take priority over Yushania Keng f., as applied in, for example, Clayton \& Renvoize (1986), Hsueh \& Li (1987) and Chao $\&$ Renvoize (1989). He proposed the conservation of the name Sinarundinaria Nakai, with Stapf's syntype from Yushania confusa conserved as type of S. nitida (Mitford ex Anon.) Nakai. This was duly considered but not felt appropriate and the proposal was rejected, largely because so very many species had been described in the genus Yushania. About 55 would require new combinations in Sinarundinaria if conserved. In addition the widely cultivated Fountain Bamboo would have required a new name. Moreover Nakai was clearly describing Sinarundinaria for the cultivated plants of Fountain and Umbrella Bamboo sent by Kew.

In the conservation proposal $\mathrm{Li}(1996)$ had pointed out that publication of Arundinaria nitida in the anonymous editorial (1895) was technically valid, on the basis of its reference to the earlier description of $A$. khasiana by Bean (1894). Brummitt (1998) confirmed this and stated the name should be cited as $A$. nitida Mitford. Although the name was indeed attributed to Mitford, the validating description was attributed to Bean (1894), and under Art. 46.5 of the Melbourne Code (McNeill $\&$ al., 2012), the authorship of A. nitida should actually in this case be cited as "Mitford ex Anon.", or just "Anon." No external evidence has been found to identify who exactly the author of this particular editorial article was. This example is unusual not only because the author of the botanical name is anonymous, but also because authorship is attributed to someone who provided neither the name (this being provided by Mitford) nor the description (this being provided by Bean). Nevertheless it would appear that "Anonymous" must be taken as the publishing author because he/she was the first to link the name and the description together (Art. 46.3 Note 3; McNeill \& al., 2012).

In this way the place of valid publication of Arundinaria nitida is Anonymous (1895) not Stapf (1896). Unfortunately, subsequent closer inspection of Anonymous (1895) has revealed that this author misunderstood and misquoted Mitford's lecture. While in the early part Mitford (1896) made it clear that he was referring his new name solely to the plants at Kew misidentified as A. khasiana, the anonymous author (1895) reported only on Mitford's concluding remarks, from which he appears to have gained the impression that Mitford was referring to the entire species $A$. khasiana:

"Arundinaria nitida, fig. 33, one of the loveliest and hardiest, to quote Mr. MitFord, was formerly called A. khasyana, under the erroneous impression that it was a native of the Khasya mountains, ... The species, it appears, is really a native of the Chinese Province of Szchuen ..."

It looks as though the anonymous author presented Arundinaria nitida as a substitute name for A. khasiana Munro, rather than as a new species as Mitford had intended, in which case it would be an illegitimate superfluous name and indeed it has been listed as such in several publications (Ohrnberger, 1988, 1999; Soreng, 2000: 22) and (as of March 2014) in online resources (Farr \& Zijlstra, 2014: Sinarundinaria; Tropicos, 2014: Arundinaria nitida).

If Arundinaria nitida Mitford were to be an illegitimate superfluous name for $A$. khasiana, then the later 1896 publications of $A$. nitida for the Fountain Bamboo would be illegitimate later homonyms. A new name would therefore be required for the Fountain Bamboo. Another undesirable consequence of this would be that $A$. nitida Mitford ex Anon., and consequently Sinarundinaria, would be typified by the type of $A$. khasiana, from Meghalaya, India. Arundinaria khasiana is well known 
and there is no doubt that it is referable to the well-recognized genus Drepanostachyum Keng f., over which the now littleused name Sinarundinaria would take priority.

Several Drepanostachyum species, including D. khasianum, have actually been transferred to Sinarundinaria in the past (Chao \& Renvoize, 1989), but that was the result of the assumption that $A$. nitida has open paniculate inflorescences, coupled with a very broad and polyphyletic generic concept for Sinarundinaria that included species of Drepanostachyum, Yushania and several other genera besides. Sinarundinaria has now settled as a synonym of Fargesia, and the Fountain Bamboo is almost universally accepted as Fargesia nitida (Li $\&$ al., 2006). The typification proposed here aims to stabilise that usage of the names.

\section{TOWARDS A SOLUTION}

To legitimise Arundinaria nitida it was at first felt necessary to propose conservation of the name with material of the Fountain Bamboo cultivated at Kew as conserved type. This would certainly have legitimised and typified it, and removed any association with A. khasiana Munro. However, this is no longer considered necessary, because it has been realised that the anonymous author of $A$. nitida implicitly excluded all the syntypes of $A$. khasiana Munro, by stating that the new species came from Sichuan in China, and not from the Khasia Mountains of India. Therefore, under Art. 52.2 of the Melbourne Code (McNeill \& al., 2012), A. nitida Mitford ex Anon. is not a superfluous, illegitimate name.
Type material for Arundinaria nitida Mitford ex Anon. clearly should be from the Fountain Bamboo grown at Kew, as this was the basis for Mitford's name, the protologue, and the validating description by Bean (1894). A sterile collection preserved at $\mathrm{K}$ in March 1895 is designated below as neotype. The protologue included a photograph (Anonymous, 1895: fig. 33; http://biodiversitylibrary.org/page/32986466) of a clump of Arundinaria nitida growing in the Bamboo Garden at Kew. A site there, with a clump of Fargesia nitida in front of an ancient, slanting oak, appearing very similar in 1999, is shown in Fig. 1. The clump started to flower that year, and died in 2001, 115 years after collection of the seed. Fargesia nitida had started to flower in the U.K. in 1993 (Stapleton, 1995), and all plants around the world derived from the initial seed collection in China are thought to have flowered and died. Fertile material, with compressed inflorescences, was collected from the clump to serve as epitype (http://apps.kew. org/herbcat/getImage.do?imageBarcode $=$ K000872530) to support the sterile neotype (http://apps.kew.org/herbcat/getImage. do? imageBarcode $=$ K000872536), which may well have come from the same plant 105 years earlier.

\section{口 TYPIFICATION}

Arundinaria nitida Mitford ex Anon. in Gard. Chron. 18: 186. 17 Aug $1895 \equiv$ Sinarundinaria nitida (Mitford ex Anon.) Nakai in J. Jap. Bot. 11(1): 1. $1935 \equiv$ Fargesia nitida (Mitford ex Anon.) Keng f. ex T.P.Yi in J. Bamboo Res. 4(2): 30.1985 $\equiv$ Thamnocalamus nitidus (Mitford ex Anon.) Demoly in
Fig. 1. Clump of Arundinaria nitida in the Bamboo Garden at Kew in 1999, just starting to flower, in a site appearing the same as that in Anonymous (1895: fig. 33; http://biodiversitylibrary. org/page/32986466).

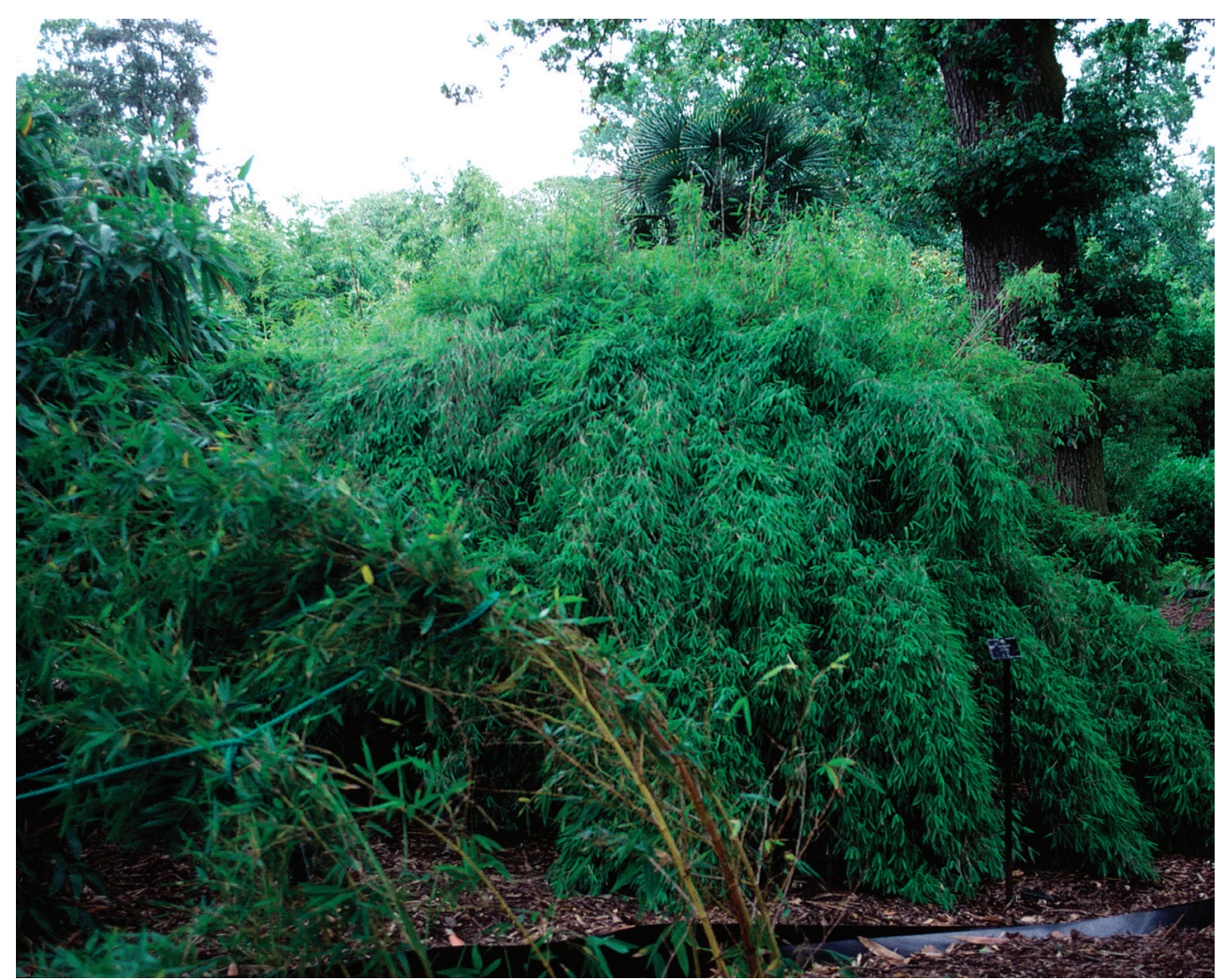


Bambou Bull. Liais. A. E. B. 9: 13. 1991 - Neotype (designated here): RBG Kew (cult.), 19 Mar 1895, s.n. (K!) - Epitype (designated here): RBG Kew (cult.), 17 Mar 2000, Stapleton 1139 (K!).

\section{ACKNOWLEDGEMENTS}

John McNeill kindly reviewed the original draft submission for conservation of the name, and advised with great clarity on the nomenclatural status of the names and authorship, and the best way to proceed to stabilise the names. Anonymous reviewers and Gerry Moore kindly helped to improve the revised manuscript.

\section{LITERATURE CITED}

Anonymous 1895. Hardy bamboos. Gard. Chron. 18: 186, fig. 33 on p. 179. http://biodiversitylibrary.org/page/32986473

Bean, W.J. 1894. A classification of hardy bamboos. Gard. Chron., ser. 3, 15: 167-168; 238-239; 301-302. http://biodiversitylibrary.org/page/25898107

Brummitt, R.K. 1998. Report of the Committee for Spermatophyta. Taxon 47: 863-872. http://dx.doi.org/10.2307/1224194

Chao, C.S. \& Renvoize, S.A. 1989. A revision of the species described under Arundinaria (Gramineae) in Southeast Asia and Africa. Kew Bull. 44: 349-367. http://dx.doi.org/10.2307/4110809

Chao, C.S., Chu, C.D. \& Hsiung, W.Y. 1981. A revision of some genera and species of Chinese bamboos. Bamboo Res. 1: 1-23.

Clayton, W.D. \& Renvoize, S.A. 1986. Genera Graminum: Grasses of the World. Richmond: Royal Botanic Gardens, Kew.

Farr, E.R. \& Zijlstra, G. (eds.) 1996+. Index Nominum Genericorum (Plantarum). http://www.botany.si.edu/ing/INGsearch.cfm ?searchword=Sinarundinaria (09 Feb 1999 entry, retrieved $10 \mathrm{Mar}$ 2015).

Franchet, M.A. 1893. Fargesia, nouveau genre de Bambusées de la Chine. Bull. Mens. Soc. Linn. Paris 2: 1067-1069.

Hsueh, C.J \& Li, D.Z. 1987. New taxa of Bambusoideae from Sichuan and Yunnan, with discussion on concepts of related genera. J. Bamboo Res. 6(2): 16-19.

Keng, P. C. 1957. One new genus and two new species of Chinese bamboos. Acta Phytotax. Sin. 6: 355-360.

Keng, P.C. 1982. A revision of genera of bamboos from the world I. J. Bamboo Res. 1(1): 1-19.

Keng, P.C. 1983. A revision of the genera of bamboos from the world III. J. Bamboo Res. 2(1): 11-27.
Li, D.Z. 1996. (1222) Proposal to conserve Sinarundinaria Nakai (Gramineae) with a conserved type. Taxon 45: 321-322. http://dx.doi.org/10.2307/1224680

Li, D.Z., Wang, Z.P., Zhu, Z.D., Xia, N.H., Jia, L.Z., Guo, Z.H., Yang, G.Y. \& Stapleton, C.M.A. 2006. Bambuseae. Pp. 7-180 in: Wu, Z.Y., Raven, P.H. \& Hong, D.Y. (eds), Flora of China, vol. 22, Poaceae. Beijing: Science Press; St. Louis: Missouri Botanical Garden Press.

McClure, F.A. 1940. New genera and species of Bambusaceae from eastern Asia. Sci. Bull. Lingnan Univ. 9: 1-67.

McNeill, J., Barrie, F.R., Buck, W.R., Demoulin, V., Greuter, W., Hawksworth, D.L., Herendeen, P.S., Knapp, S., Marhold, K., Prado, J., Prud'homme van Reine, W.F., Smith, G.F., Wiersema, J.H. \& Turland, N.J. (Eds.) 2012. International Code of Nomenclature for algae, fungi, and plants (Melbourne Code): Adopted by the Eighteenth International Botanical Congress Melbourne, Australia, July 2011. Regnum Vegetabile 154. Königstein: Koeltz Scientific Books. http://www.iapt-taxon.org/nomen/main.php

Mitford, A.B.F. 1896. Hardy bamboos. J. Roy. Hort. Soc. 19: 359-374.

Nakai, T. 1935. Novitates Bambusacearum in Imperio Japonico recentissime detectae III. J. Jap. Bot. 11(1): 1-9.

Ohrnberger, D. 1988. The bamboos of the World: A preliminary study; Genus Fargesia, ed. 1. Langweid am Lech: distributed by the author.

Ohrnberger, D. 1999. The bamboos of the World. Amsterdam, New York: Elsevier.

Soderstrom, T.R. 1979a. The bamboozling Thamnocalamus. Garden (New York 1977+) 3(4): 22-27.

Soderstrom, T.R. 1979b. Another name for the umbrella bamboo. Brittonia 31: 495 . http://dx.doi.org/10.2307/2806007

Soreng, R.J. (ed.) 2000. Catalogue of New World grasses I. Contr. U.S. Natl. Herb. 39: 1-128.

Stapf, O. 1896. 230. Arundinaria nitida, Mitford. Pp. 20-21 in: Decades Kewenses: Plantarum novarum in herbario horti regii conservatorum-Decas XXIII-XXV. Bull. Misc. Inform. Kew 1896: 16-26. http://biodiversitylibrary.org/page/40914127

Stapleton, C.M.A. 1991. A morphological investigation of some Himalayan bamboos with an enumeration of taxa in Nepal and Bhutan. Unpublished Ph.D. thesis, University of Aberdeen, U.K

Stapleton, C.M.A. 1995. Flowering of Fargesia nitida in the UK. Bamboo Soc. Newslett. 22: 17-22. http://www.bamboo-identification.co.uk/stap01.pdf

Tropicos 2014. Tropicos.org. Missouri Botanical Garden http://www.tropicos.org/Name/25508733 (accessed 14 Mar 2014).

Wang, Z.P. \& Ye, G.H. 1980. On the problems of the classification of Chinese bamboos with creeping rhizomes. Acta Phytotax. Sin. 18: 283-291. http://www.jse.ac.cn/wenzhang/FL18-3-3.pdf

Yi, T.P. 1983. New taxa of Bambuso1deae from X1zang (Tibet), China. J. Bamboo Res. 2(1): 28-46. 